\title{
CREDIT CONSTRAINTS IN GENERAL EQUILIBRIUM: EXPERIMENTAL RESULTS
}

\author{
Antoni Bosch-Domènech \\ and \\ Joaquim Silvestre
}

Working Paper Series \#95-07

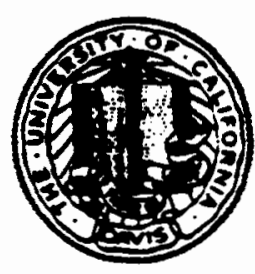

Department of Economics

University of California

Davis, California 95616-8578 


\title{
CREDIT CONSTRAINTS IN GENERAL EQUILIBIUUM: EXPERIMENTAL RESULTS
}

\author{
Antoni Bosch-Domènech* and Joaquim Silvestre
}

\author{
Working Paper Series No. 95-07 \\ February 1995
}

We gratefully acknowledge the research assistance of Humberto González Llavador,

Rosa Inés Gonzalez, Estela Murúa de Hopenhayn and Carles Perarnau, and financial support from the Spanish Ministry of Education and Science under contract DGICYT PB 92-0593-C0202

\section{*Universitat Pompeu Fabra}

Note: The Worlcing Papers of the Department of Economics, University of California, Davis, are preliminary materials circulated to invite discussion and critical comment. These papers may be freely circulated but to protect their tentative character they are not to be quoted without the permission of the author. 


\title{
Credit Constraints in General Equilibrium: Experimental Results
}

\begin{abstract}
Our work attempts to investigate the influence of credit tightness or expansion on activity and prices in a multimarket set-up. We report on some doubleauction, two-market experiments where subjects had to satisfy an inequality involving the use of credit. The experiments display two regimes. characterized by high and low credit availability. The critical value of credit at the common boundary of the two regimes has a compelling interpretation as the maximal credit use at the Arrow-Debreu equilibrium of the abstract economy naturally associated to our experimental environment. Our main results are that changes in the availability of credit: (a): have minor and unsystematic effects on real and nominal variables in the high-credit regime; (b): have substantial effects, both real and nominal, in the low-credit regime.
\end{abstract}

Journal of Economic Literature Classification: C92, D44, D51 


\section{Motivation}

The Arrow-Debreu model, which is the canonical representation of interactions among markets, postulates perfect credit worthiness. But it is not clear that this is an accurate description of modern economies. Credit availability may play a substantive role both in the level of economic activity and in price formation.

Our work attempts to experimentally investigate the influence of credit tightness or expansion on activity and prices in a multimarket set-up. To this end, we design an experiment with two markets: input (labor) and output. We try to capture credit constraints it their simplest, static form: they appear, in our experiments, as lower bounds on the balances of numeraire. We run several experiments at different levels of the constraints for the buyers of output.

\section{The experiments}

\subsection{Environment}

We keep the environment as simple as possible. There are two types of subjects, consumer-workers and consumer-producers. We have six, diverse consumer-workers, who sell input and buy output. There are also four identical consumer-producers who buy input, transform it into output, and sell it.

As is customary in market experiments. we control the preferences, endowments and technology as follows. We endow consumer-workers with initial quantities of the input, and we assign them schedules of redemption values, positive for output bought, and negative for input sold. A consumer worker's final payoff is the algebraic sum of her redemption values (of the units of output bought and input sold) plus any sales receipts net of purchase outlays. Producers are assigned a transformation schedule; their payoffs are simply profits, i.e., sates receipts minus purchase outlays. The schedules are identical, to the ones in Goodfellow and Plott (1990).

More specifically, for consumer-worker $i(i=1, \ldots, 6)$ write $x_{i 2}$ for the total amount of output that she buys. and $L_{i}$ for the total amount of input that she sells. Denote by $v_{i}\left(x_{i 2}\right)$ i's total redemption value of $x_{i 2}$ units of output (that she has acquired). The data are given as marginal redemption values 
$\Delta v_{i}\left(x_{i 2}\right)=v_{i}\left(x_{i 2}\right)-v_{i}\left(x_{i 2}-1\right)$, where $v_{i}(0)=0$, in units of the lab unit of exchange, the Leexeta. Table I expresses consumer-worker i's marginal redemption values (same for all consumers).

Table I. Marginal redemption value table for each of six consumers of output (in Leexeta)

\begin{tabular}{|c|c|}
\hline Unit & Marginal Redemption \\
\hline$x_{i 2}$ & $\begin{array}{r}\text { Value } \\
\Delta v_{i}\left(x_{i 2}\right)\end{array}$ \\
\hline 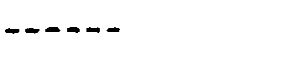 & 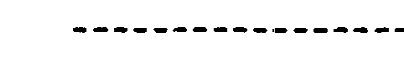 \\
\hline 1 & 98 \\
\hline 2 & 88 \\
\hline 3 & 78 \\
\hline 4 & 70 \\
\hline 5 & 60 \\
\hline 6 & 50 \\
\hline 7 & 43 \\
\hline 8 & 33 \\
\hline 9 & 25 \\
\hline 10 & 15 \\
\hline 11 & 10 \\
\hline 12 & 5 \\
\hline 13 (or more) & 0 \\
\hline
\end{tabular}

Write $c_{i}\left(L_{i}\right)$ for $i$ 's negative "redemption" value, or cost, of $L_{i}$ units of input (that she has delivered). The values now diverge among consumers. They are given. again as "marginal cost" values $\Delta c_{i}\left(L_{i}\right)=c_{i}\left(L_{i}\right)-c_{i}\left(L_{i}-1\right)$, (where $c_{i}(0)=$ o) in Table 11 . 
Table II. Marginal cost schedule for six sellers of input

(in LeeXeta)

\section{Consumer-Worker Number}

\begin{tabular}{lcccccc} 
Unit & 1 & 2 & 3 & 4 & 5 & 6 \\
$L_{i}$ & $\Delta c_{1}\left(L_{1}\right)$ & $\Delta c_{2}\left(L_{2}\right)$ & $\Delta c_{3}\left(L_{3}\right)$ & $\Delta c_{4}\left(L_{4}\right)$ & $\Delta c_{5}\left(L_{5}\right)$ & $\Delta c_{6}\left(L_{6}\right)$ \\
\hline 1 & 10 & 35 & 50 & 65 & 80 & 100 \\
2 & 150 & 165 & 180 & 205 & 130 & 115 \\
3 & 275 & 310 & 255 & 295 & 235 & 220 \\
4 & 400 & 400 & 400 & 400 & 400 & 400 \\
5 & 1000 & 1000 & 1000 & 1000 & 1000 & 1000
\end{tabular}

Write $R_{i}$ for $i$ 's total receipts from her input sales, and $D_{i}$ for i's total expenditure in purchasing output. For $\mathfrak{i}=1, \ldots .6,6$, consumer-worker i's payoff is then

$$
v_{i}\left(X_{i 2}\right)-C_{i}\left(L_{i}\right)+R_{i}-D_{i}
$$

The four consumer-producers have identical production schedules $f_{i}\left(-y_{i 1}\right)$. where $-y_{i 1}>0$ is the amount of input used. The individual production schedule is again given by the individual marginal outputs of Table III. We write $\operatorname{Af}_{i}(0)=$ 0. and, for $-y_{i 1} \geq 1, \Delta f_{i}\left(-y_{i 1}\right)=f_{i}\left(-y_{i 1}\right)-f_{i}\left(-y_{i 1}-1\right)$. 
Table III. Individual production schedule $(i=1, \ldots .4)$

\begin{tabular}{cc} 
Input & Individual Marginal Output \\
\hline$-y_{\text {it }}$ & $\Delta f_{\mathrm{i}}\left(-y_{\mathrm{i} 1}\right)$ \\
\hline 0 & 0 \\
1 & 7 \\
2 & 5 \\
3 & 5 \\
4 & 3 \\
5 & 3 \\
6 & 1 \\
7 & 1 \\
8 (and above) & 0
\end{tabular}

2.2. Institutions

Both markets are double auctions. Any buyer can submit a bid (to buy) a single unit of a good at any time. Two conditions must be fulfilled for the bid to be recognized as a valid bid by the market. First, the bid must exceed any existing bid that may be present in the market. Second. the originator of the bid must have the ability to settle the transaction at that bid. Similarly, any seller can submit an ask (to sell) at any time. Again, for the ask to be valid. two analogous conditions must be fulfilled: the ask must be lower than any existing ask in the rnarket and the proposed transaction should be possible.

A higher bid becomes the current bid and a lower ask becomes the current ask in the market. Current bid and ask are the only ones standing in the market at any time: all superseded bids and asks are cancelled, i.e., there is no queue. A transaction is executed when a buyer accepts the current' ask or a seller accepts a current bid. The price at which the transaction is recorded is the current ask or bid. The markets are open for a specified period of time.

Both consumer-workers and consumer-producers are subject to a credit constraint: the balance of receipts minus expenditures cannot be lower than a prespecified level at any point in time. The level is constant across experiments in what concerns consumer-producers, but takes different values 
for consumer-workers. In a given experiment consumer-workers are assigned a certain level k of maximal indebtedness: this defines their credit constraints.

\subsection{Behavior}

We ran sixteen experiments at several levels of $k$ ranging from $k=0$ to $k=$ 1000 , and with a variable number of iterations or periods in each experiment. All periods of a given experiment have the same subjects, but, otherwise, each period is independent from any other one. In particular, balances of numeraire cannot be carried from a period to the next one, and the payoffs in a period are unrelated to what happens in any other one. We compare last-period levels of transactions in input and output, and some statistic of the prices at which transactions take place.

A summary of the experimental results is provided in Table IV and Figures 1-5. Each row of Table IV corresponds to one of the sixteen experiments and offers some values obtained in the last period of the experiment. The first column is the credit limit k. The second (resp. third) one is the total number of transactions in input (resp. output). The 'fourth (resp. fifth) column lists the average price at which input (resp. output) transactions took place. The entry in the sixth column divides the fourth column by the fifth one: thus, it gives the relative input price or "real wage.' The last column displays the 'relative efficiency," i.e., the gains from trade (or sum of

producers' and consumers' surpluses) $\sum_{i=1}^{6}\left[v_{i}\left(x_{i 2}\right)-c_{i}\left(L_{i}\right)\right]$. relative to their maximal value, which is the one in the Arrow-Debreu equilibrium.

The last row of Table IV gives, for reference purposes, the Arrow-Debreu equilibrium values. 
Table IV Summary of Experimental Results

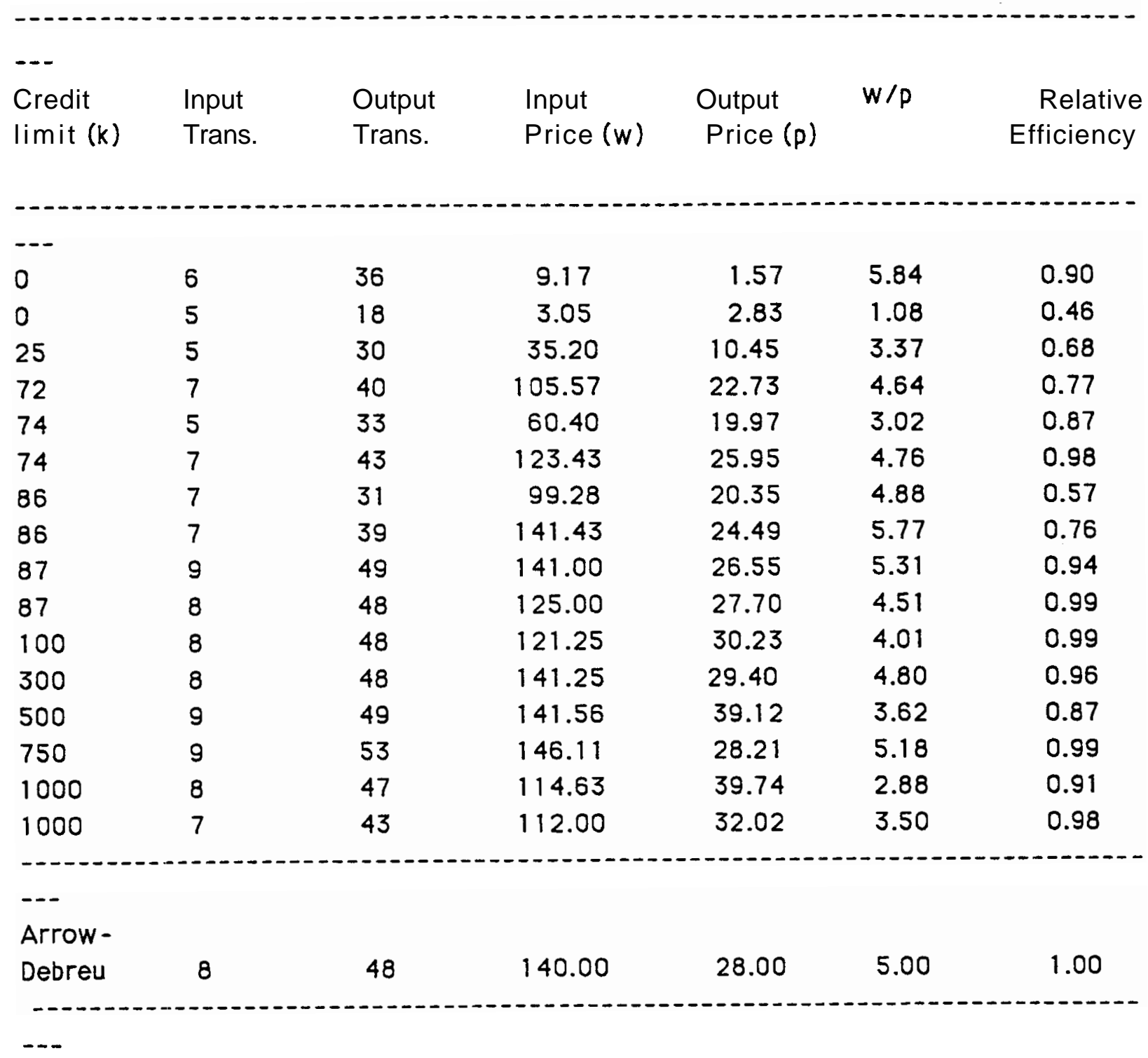

Figures 1 to 5 plot the mean values in Table IV (input transactions. input price, output transactions, output price and efficiency) for every level of $\mathbf{k}$. 


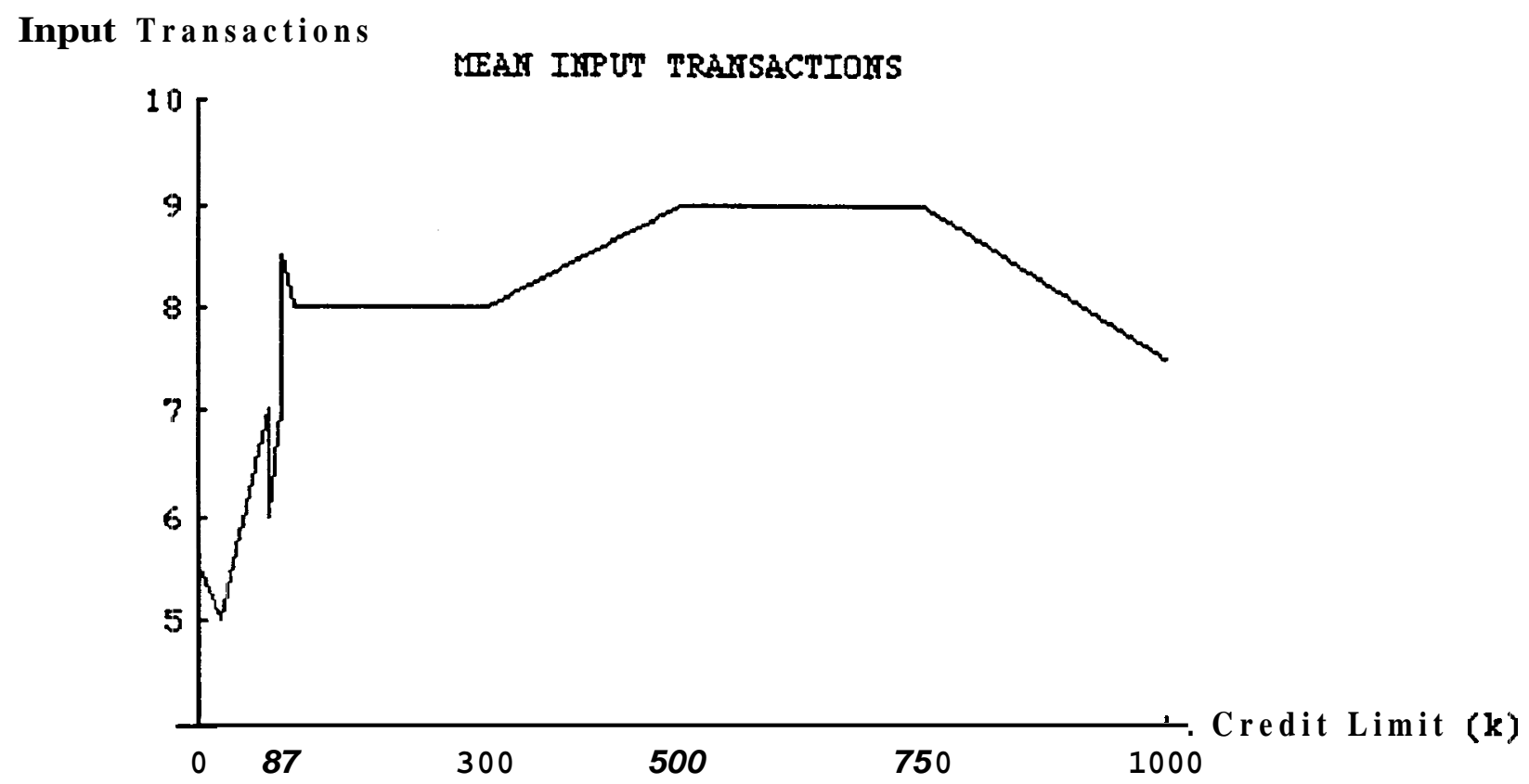

Fig 1. Mean Input Transactions

\section{Output \\ Transactions}

MEÂR OUTPUT

TRARSACTIONS

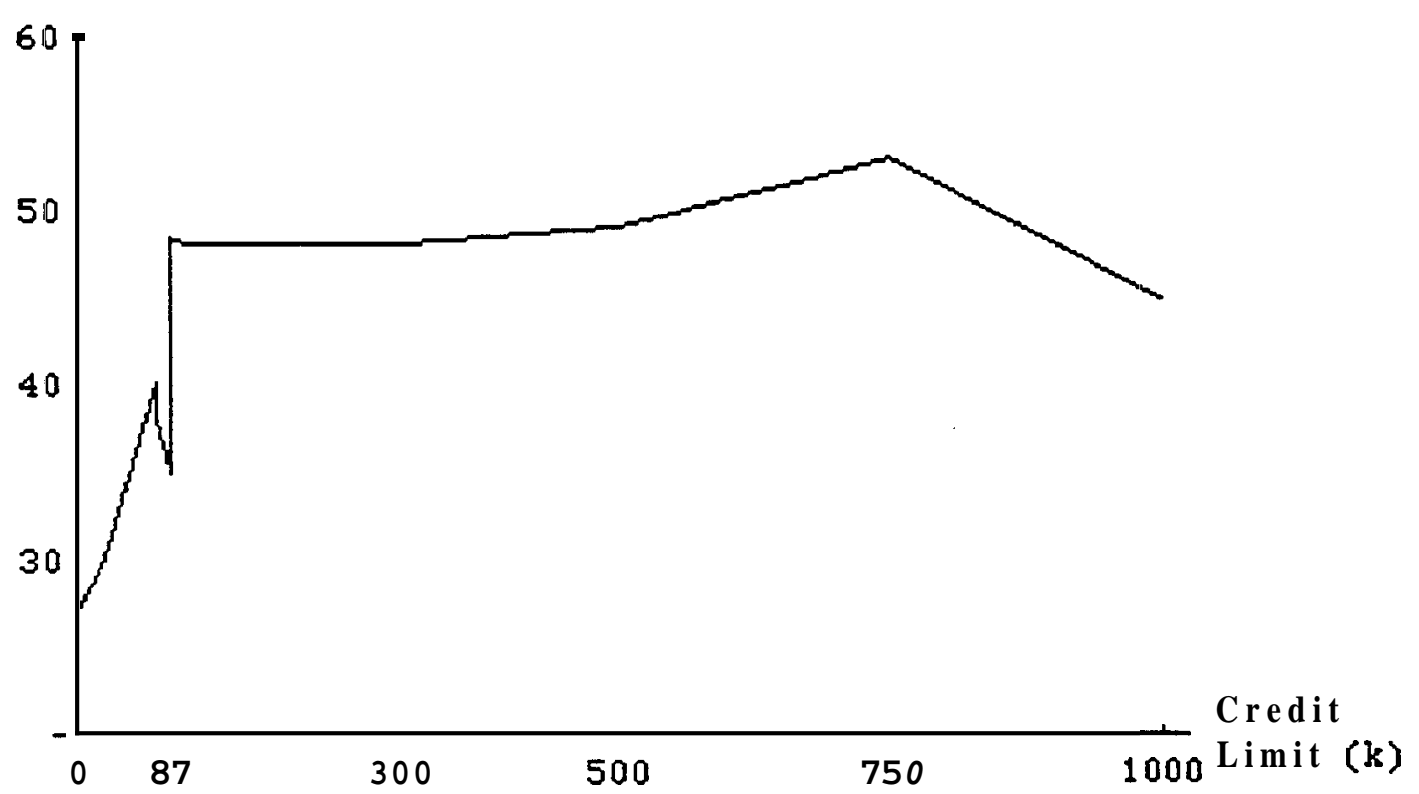

Fig 2. Mean Output Transactions 


\section{Input \\ Price}

WEA IMPUT

PRICE

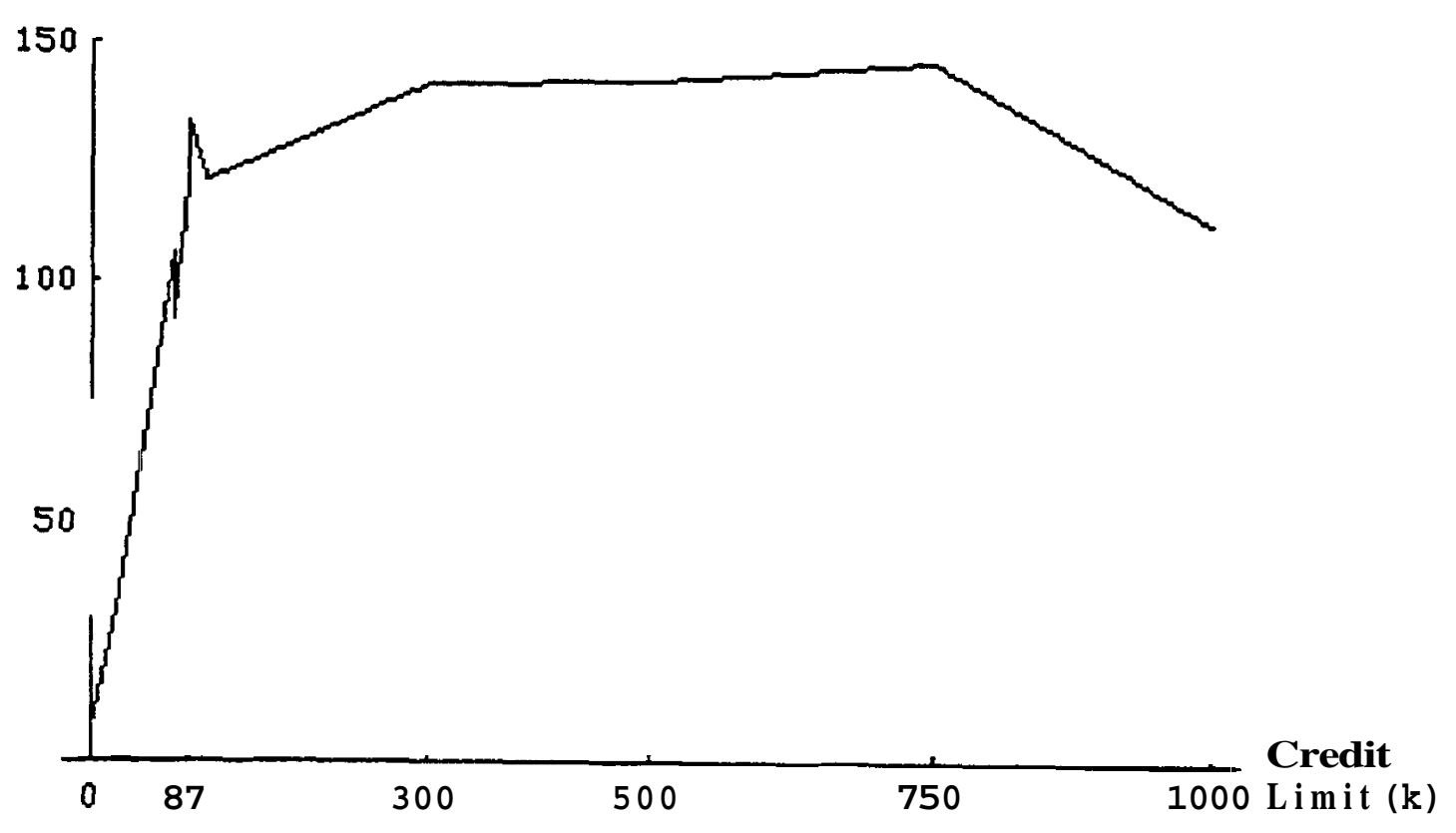

Fig 3. Mean Input price 


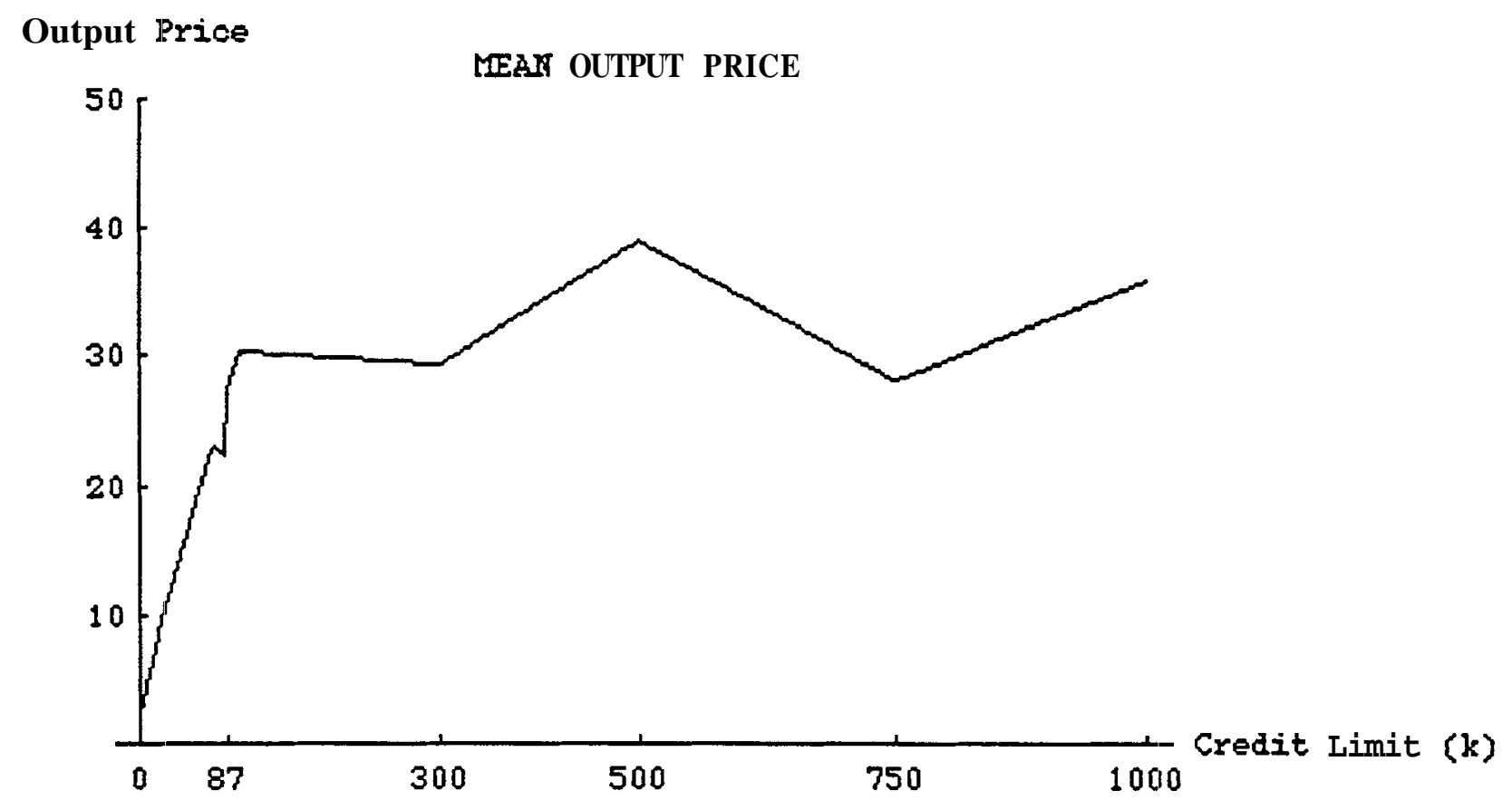

Fig 4. Mean Output Price

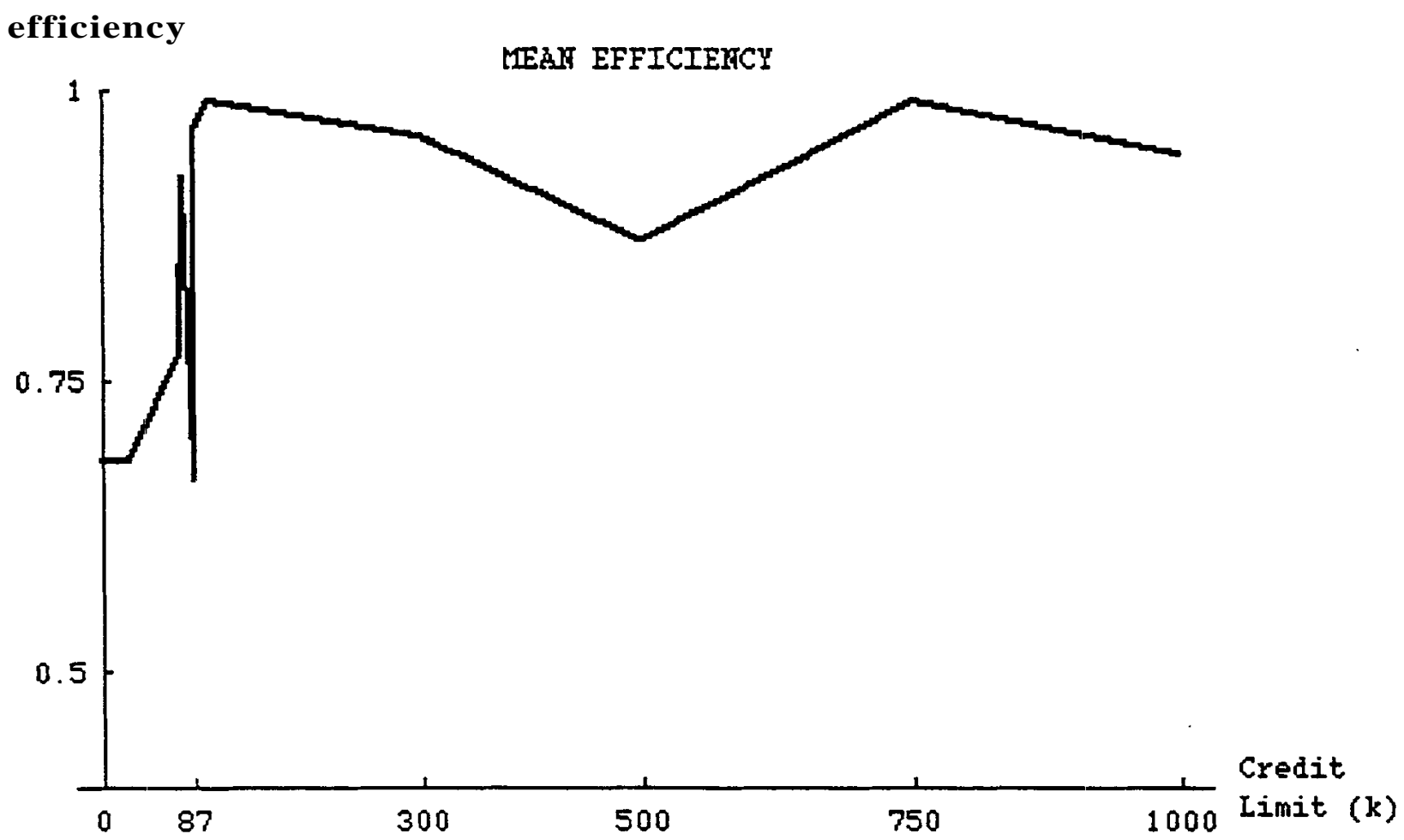

Fig 5. Mean Efficiency 
Table IV, Figures 1-5 and Section A5 in the Appendix support the following stylized facts.

\section{Prices}

(1) Prices are close to zero for k close to zero.

(2) As $k$ increases from zero up to a certain level, average prices increase steeply.

(3) After a certain level of $k$. average prices stop increasing and their trend becornes more stationary.

$\underline{\text { Transactions }}$

(4) Input and output transactions move together following the aggregate production function, i.e., economy wide productive efficiency obtains.

(5) The average level of transactions varies significantly with $k$ at low levels of $\mathrm{k}$.

(6) The average level of transactions is high and shows little sensitivity to $k$ for $k$ high enough.

(7) The average level of transactions is bounded well above zero, no matter how low $\mathrm{k}$ is (input transactions, for instance, do not drop below 5 units per period. while they average between 8 and 9 at high $k^{\prime} s$ ).

Efficiency

(8) Ef ficiency is close to $100 \%$ for high $\mathrm{k}$ 's; when $\mathrm{k}$ is low, efficiency oscillates 'from below 50 percent to the high 90 percents.

3. Double-auction experiments and price-taking models

The trading institution in the experiments is a double auction. Models of rational behavior in double auction are few and involve a high degree of complexity. Wilson's (1987) is the best know analysis of double auction as a game of incomplete information. Efforts have also been made to model double auction as a game of complete information. Neither of these game-theoretical models nor other attempts have been completely successful' ${ }^{1}$. On the other hand, since Smith (1962) it has been known that, in laboratory experiments, double-auction institutions consistently produce efficient allocations and prices close to the predictions of price-taking models. These predictions are

1 see Frieclman (1993) for references. 
even sustained when subjects are random decision-makers as in Bosch and Sunder (1994). It is therefore natural that. as long as we are not concerned with the dynamics of individual behavior, we look at a price-taking model, like the general equilibrium approach of Arrow-Debreu, to provide the theoretical underpinnings of the market-wide outcomes observed in the laboratory.

\section{An Arrow-Debreu model with credit constraints}

\subsection{Concept}

The formal model is Arrow-Debreu's (with three goods and quasilinear preferences, i.e., linear in the numeraire good) except that it has the added feature of credit constraints. 2 We describe it in the detailed, canonical format.

We first formalize the agents in the model: firms and consumers. There are four firms. Firm $i(i=1, \ldots, 4)$ is defined by the production set:

$$
Y_{i}=\left\{\left(y_{i 1}, y_{i 2}\right) \in R^{2}: y_{i 1} \in \Omega_{i} \text { and } y_{i 2} \leq f_{i}\left(-y_{i 1}\right)\right\} \text {, }
$$

where $\Omega_{i}$ is the domain on which $f_{i}$ is defined (a subset of the: nonpositive integers in our experimental environment), and where we follow the general equilibrium convention of writing the use of an input as a nonpositive number $y_{i 1}$, and the supply of output as a nonnegative number $y_{i 2}$.

There are 10 consumers in total. Consumers 1 to 6 are! the formal counterparts of the experimental consumer-workers. Consumer $i, i=7, \ldots, 10$, is a fictional consumer-capitalist. sole owner of firm i-6, and interested only in the consumption of numeraire.

The experimental payoff data induce an agent's preferences in a rather incontestable way, as soon as we accept the premise that she prefers a higher payoff to a lower one. Consider consumer-worker $i, i=1, \ldots, 6$. Because her payoff in the experiment is $v_{i}\left(x_{i 2}\right)-c_{i}\left(L_{i}\right)+R_{i}-D_{i}$. it is natural to formalize her by:

a vector of initial endowments $\left(\omega_{i 1}, \omega_{i 2}, \omega_{i 3}\right)$ where $\omega_{i 1}>0$, and

$$
\omega_{i 2}=\omega_{i 3}=0_{i}
$$

2 Because credit constraints place lower bounds on the holdings of the numeraire good, income effects may appear at the boundary. when credit constraints are binding. despite the quasilinear form of the utility function. 
* the consumption set $\hat{x}_{1} \times x_{2} \times R$, where $\hat{x}_{1}=\left\{\omega_{i_{1}}\right\}-x_{1}, x_{1}$ is the set of values $L_{i}$ of the input for which $c_{i}$ is defined, and $X_{2}$ is the set of values $x_{i 2}$ for which $v_{i}$ is defined (both $x_{1}$ and $x_{2}$ are intervals of the nonnegative integers in our experimental environment).

* the preference relation represented by the utility function:

$u_{W}: \hat{x}_{1} \times x_{2} \times R: u_{W}\left(x_{i 1}, x_{i 2}, x_{i 3}\right)=-c_{i}\left(\omega_{i 1}-x_{i 1}\right)+v_{i}\left(x_{i 2}\right)+x_{i 3}$.

where $x_{i 3}$ corresponds to the experimental $R_{i}-D_{i}$. $i$ 's final

balance of the numeraire good.

* the vector of profit shares $\left(\theta_{i 1}, \theta_{i 2}, \theta_{i 3}, \theta_{i 4}\right)=(0,0,0,0)$.

Consumer $\mathrm{i}(\mathrm{i}=7, \ldots, 10)$ is defined by:

* the vector of initial endowments $\left(\omega_{i 1}, \omega_{i 2}, \omega_{i 3}\right)=0$;

* the consumption set $\{0\} \times\{0\} \times \mathrm{R}$,

* the preference relation represented by the utility function: $u_{c}:\{0\} \times\{0\} \times R \rightarrow R: u_{c}(x i 1, x i 2, x i 3)=x i 3 ;$

* the vector of profit shares profit shares $\left(\theta_{i 1}, \theta_{i 2}, \theta_{i 3}, \theta_{i 4}\right)$, where $\theta_{i, i-6}=1$, and $\theta_{i j}=0$ for $j=i-6$.

We emphasize that the modelling of preferences and technology follows quite unambiguously from the data in the experimental environment: to the extent that we are entitled to assume that the experimental subjects prefer larger payoffs, there is little freedom in formalizing their preferences. Modelling behavior is quite another matter. To this we turn now.

We postulate that all agents take as given the market price of input $\mathrm{w}$, the market price of output $p$, and the price of the numeraire good. which is identically equal to one.

They also take as given some credit constraints. The experiment introduces credit constraints as a lower bound on the net balances of numeraire to be satisfied at each point of time. But the observed timing of transactions in the experiment has a very definite pattern. First, transactions in input occur. and, then, output is bought and sold. This justifies capturing the experimental constraint as a weaker condition involving total expenditure in output and total receipts from the input sale. 3 Recalling that $k$ denotes the credit limit, we formalize i's credit constraint, $\mathrm{i}=1, \ldots ., 6$, as $p x_{i 2}-w L_{i}-k \leq 0$.

3 Formally, if we denote by $z_{t}$ the difference between expenditures and receipts up to instant $t$. the actual experimental rule requires $\mathbf{z} \leq \mathbf{k}$, for all $\mathrm{t}$. 
Definition: An equilibrium for the credit constraints $k$ is a vector

$\left(\bar{w}, \bar{p},\left\{\left(\bar{L}_{i}, \overline{x_{i 2}}, \overline{x_{i}}\right), i=1, \ldots, 6\right\},\left\{\overline{x_{i}}, \quad i=7, \ldots, 10\right\},\left\{\left(\overline{y_{i}} 1, \overline{y_{i 2}}\right), i=1, \ldots, 4\right\}\right) \in$ $R^{32}$

such that:

1. (w, 可 $\geq 0$.

2. For $i=1, \ldots, 4,\left(\bar{y}_{i 1}, \overline{y_{i 2}}\right)$ maximizes $\bar{p} y_{i 2}+\bar{w} y_{i 1}$ on $Y_{i}$.

3. For $i=1, \ldots, 6 . \quad\left(\bar{L}_{i}, \overline{x_{i 2}}, \overline{x_{i 3}}\right)$ maximizes $-c_{i}\left(L_{i}\right)+v_{i}\left(x_{i 2}\right)+x_{i 3}$

subject to: $\overline{\mathrm{p}} \mathrm{x}_{\mathrm{i} 2}+\mathrm{x}_{\mathrm{i} 3} \leq \bar{w} L_{i}$ (budget constraint), and: $\bar{p} x_{i 2} \leq \bar{W} L_{i}+k \quad$ (credit constraint).

For $\mathrm{i}=7, \ldots, 10$,

$\bar{x}_{i 3}$ maximizes $x_{i 3}$ subject to: $\bar{p} x_{i 3} \leq \bar{p} \overline{y_{i}-6,2}+\bar{w} \overline{y_{i}-6,1}$.

4. $\sum_{i=1}^{6} \overline{x_{i 2}}-\sum_{i=1}^{4} \overline{y_{i 2}}=0$.

$\sum_{i=1}^{6} \Gamma_{i}+\sum_{i=1}^{4} \bar{y}_{i 1}=0$.

$\sum_{i=1}^{10} \overline{x_{i 3}}=0$.

The usual concept of an Arrow-Debreu equilibrium is obtained by deleting the credit-constraint inequalities $\overline{D x}_{i_{2}} \leq \bar{w} L_{i}+k, i=1, \ldots, 6$, in 'the previous definition. 4

4.2. Arrow-Debreu equilibrium values.

It is not difficult to compute that, with the preferences and technology given by the experimental environment, there is a unique Arrow-Debreu equilibrium allocation $a^{*}=\left\{\left(L_{i}{ }^{*}, x_{i 2}{ }^{*}, x_{i 3}{ }^{*}\right), i=1, \ldots, 6\right\},\left\{x_{i 3}{ }^{*}, i=7, \ldots, 10\right\},\left\{\left(y_{i 1}{ }^{*}, y_{i 2}{ }^{*}\right), i\right.$

${ }^{4}$ The Arrow-Debreu notion coincides with the equilibrium concept in Goodfellow-Plott. As mentioned in 2.1. above. we also adopt the same parameters. See Section 5.1 below for a comparison. 
$=1, \ldots, 4\})$. It implies aggregate input transactions of 8 units, and aggregate output transactions of $\mathbf{4 8}$ units.

The experimental data are discrete, which enables the Arrow-Debreu equilibrium allocation to be supported by a continuum of price pairs. namely, by any $(w, p)$ in the set:

$$
S^{*}=\left\{(w, p) \text { in } R^{2}: w=5 p, 26 \leq p \leq 30,130 \leq w \leq 150\right\} \text {. }
$$

i.e., the equilibrium relative input price is $w / p=5$. (This follows from the profit maximization conditions). In other words, (w, $p,\left\{\left(L_{i}^{*}, x_{i 2}{ }^{*}, x_{i 3}{ }^{*}\right), \mathbf{i}=\right.$ $1, \ldots, 6\},\left\{x_{i 3}{ }^{*}, i=7, \ldots, 101,\left\{\left(y_{i 1} *, y_{i 2}{ }^{*}\right), \mathbf{i}=1, \ldots, 4\right\}\right)$ is an Arrow-Debreu equilibrium for any $(w, p)$ in $S^{*}$.

\subsection{The effects of credit constraints}

Take a $(w, p)$ in $S^{*}$ and define $E=\left(w, p,\left\{\left(L_{i}^{*}, x_{i 2}{ }^{*}, x_{i 3}{ }^{*}\right), i=1, \ldots, 6\right\},\left\{x_{i} 3^{*}, i=\right.\right.$ $\left.7, \ldots, 10\},\left\{\left(y_{i 1}{ }^{*}, y_{i 2}{ }^{*}\right), i=1, \ldots, 4\right\}\right)$, i.e., $E$ is an Arrow-Debreu equilibrium. For $i=1, \ldots .6$ define $\overline{k_{i}}=p x_{i 2}{ }^{*}-w L_{i}{ }^{*}$, and $\bar{k}=\max i \in\{1 \ldots, 6\} \overline{k_{i}}$. It is clear that if $k \geq \pi$, then $E$ is an equilibrium for the credit constraints $k$, because $E$ satisfies all the credit inequalities at $k$. In other works, if $k \geq \bar{k}$. then $E$ is an equilibrium for $k$.

If, on the contrary, $k<\bar{k}$, then clearly $E$ cannot be an equilibrium for $k$. because $E$ violates at least one of the credit constraints. Thus. if $k<\bar{k}$. then any equilibrium for $k$ will have either prices or quantities (or both) different from those in E. In fact, both the price pair and the real allocation vary with $\mathrm{k}$ for economic environments of the type considered here.

The value $\bar{k}$ depends on the particular $(w, p) \in S^{*}$. It turns out that the interval of admissible $\bar{K} s$ is the interval [78, 90]. 5 As soon as the credit constraint falls below 78, explicitly solving the model becomes problematic. The original model being discrete, it is highly discontinuous. Smoothing out the data and choosing differentiable functions works fine for computing the ArrowDebreu equilibrium allocation, but the equalities and inequalities defining credit constrained! equilibria are fundamentally altered.

We have performed back-of-the-envelope computations for several combinations of discrete and smoothed data. which have convinced us that the

5 Several of our experiments set $k$ at 86 and 87 , close to the upper end of this range. 
computed level of transactions for k below 78 differs from the Arrow-Debreu equilibrium values, but remains relatively high even when $\mathrm{k}$ becomes arbitrarily small. This is in agreement with Stylized Fact 7 above. In turn, quantities being well above zero as $\mathrm{k}$ becomes small implies that input and output prices must then tend to zero with $k$. This is consistent with Stylized Fact 1 above.

The numerical values of the equilibrium quantities transacted at $k<78$ turn out to be very sensitive to the particular combination of smooth and discrete data used for the computations. Therefore, we do not place much faith on any of the various computed values, and we do not claim a clear match between the model and Stylized Facts 2 and 5. Yet, all versions predict that quantities do change with $k$ for values of $k$ below some critical value between 78 and 90. And if one combines the original, discrete data for the technology and the valuation of the input with a smoothed out valuation of the output. then aggregate input transactions remain at 8 for the Arrow-Debreu equilibrium. but drop to 6 at the credit-constrained equilibria for low k. This is in 'line with the experimental results, where aggregate input transactions range from 5 to 7 for k low.

5 Comparison with the literature

The present paper shares a basic feature with Goodfellow-Plotl: (1990) and Lian-Plott (1994): they all have two-market, double-auction experiments with well-defined preferences. 6

\subsection{Goodfellow-Plott (1990)}

Our experimental set-up is identical to theirs, with one difference: they keep the credit constraint at $k=1000$ in all experiments. while we try a variety of values for $k$ between zero and one thousand, enabling us to investigate the effects of credit.

6 The paper Bosch-Sunder (1994), mentioned in Section 3 above, does have two markets, , but its actors lack well-defined preferences. 
The theoretical model postulated in Goodfellow-Plott (1990) is the Arrow-Debreu model (see Section 4 above), instead of our equilibrium with credit constraints. But because, as observed in Section 4.3, for large $\mathrm{k}$ our equilibria coincide with the ones of the Arrow-Debreu model, the results of our experiments for $\mathrm{k}$ large replicate theirs. The overall picture is that our results do reproduce the ones in Goodfellow-Plott. They obtain the convergence of quantities and price pairs to the Arrow-Debreu equilibrium values, and so do we for large k. But we observe somewhat lower input prices, and on occasion higher output prices: this yields real input prices generally lower than the ones predicted by the Arrow-Debreu model and more prevalent in the GoodfellowPlott experiments. At first blush, this could suggest the presence of some market power in the hands of producers. ${ }^{7}$ But we feel that the double auction mechanism is rather effective in preventing the exercise of market power even with few participants. We tend to adscribe the discrepancies from the ArrowDebreu price predictions to the fact that, as discussed in Section 3 above and emphasized by Goodfellow-Plott (1990, Section V), the isomorphism between double auctions and price taking is far from exact.

\subsection{Lian-Plott (1994)}

This recent paper offers an interesting experimental test of the Arrow-Debreu model. We compare it with ours along three lines.

\subsubsection{Preferences}

As argued in Sections 2.1 and 4.1 above, preferences are given by the experimenter to the extent that subjects are interested only in their final payoffs. In our experiments, preferences are defined on three goods: input. output and the numeraire, and preferences are quasilinear (i.e., linear in the nurneraire good). Lian-Plott, on the contrary, have non-quasilinear preferences defined on two goods: input and output. They do have money, but money does not enter the utility function. 8

5.2.2. Theoretical models and predictions

7 Indeed, despite their higher relative input prices. Goodfellow-Plott (1990, footnote 2) view their own results as consistent with Cournot oligopo'ly.

8 Lian-Plott allow agents to exchange final money balances against input and output in order to give agents an incentive to hold money at the closing of the experiment. 
Lian-Plott have essentially an Arrow-Debreu model. ${ }^{9}$ The model predicts the real allocation and the ratio (price of input/price of output) of the Arrow Debreu equilibrium. Moreover, there is outside money in fixed supply $M^{s}$ which serves as a medium of exchange. The Arrow-Debreu model is complemented by a 'quantity theory' equation: if the velocity of money is constant, then an increase in the money supply equiproportionally raises prices.

The theoretical differences between Lian-Plott's money supply $\mathrm{M}^{\mathrm{S}}$ and our credit bound $k$ should be emphasized. In the model of Lian-Plott. changes in $M^{s}$ never affect real variables or relative prices, and generate equiproportional changes in absolute prices as long as the velocity of money is constant. In our model, on the contrary, changes in the credit bound $k$ have no effects (real or nominal) when $\mathrm{k}$ is high, and may affect everything (real variables, and absolute and relative prices) for $\mathrm{k}$ low.

\section{2. 3. Experimental results}

The economic environment of Lian-Plott is different from the one in our paper (which is the same as Goodfellow-Plott's): two goods versus three, and non-quasilinear versus quasilinear utilities, which implies the presence of income effects in the Lian-Plott model. But both (ours only for high $k$ ) experimentally test the predictions of an Arrow-Debreu model with an input market and an output market.

Consider first real variables and relative prices. There are some divergences between their experimental results and ours. We tend to observe. for large k. quantities that are equal to or even larger than their Arrow-Debreu equilibrium values, while the observed relative price of the input is somewhat lower than the equilibrium value. In Lian-Plott, on the contrary, relative prices are close to their Arrow-Debreu values, while quantities of both input and output fall short of equilibrium (see their Figures 4 and 5.)

Concerning nominal variables, the experimental results match the theoretical differences between their money supply $M^{S}$ and our credit limit $k$. Lian-Plott's results on the behavior of absolute prices as $M^{S}$ changes are consistent with the quantity theory when the velocity of money is constant. In

\footnotetext{
9 With several interconnected periods and some minor twists. For instance, producers maximize an increasing function of profits in units of input, which is theoretically indistinguishable from the profit maximization of the canonical Arrow-Debreu model. The redemption of final money balances referred to in the previous footnote implies that the experiments violate resource constraints (there is some final consumption of output in excess of production, or some final use of input in excess of endowments). But the violation is quantitatively insignificant.
} 
their words (p. 26). "prices are on the order of proportional to the money supply."

In our case, increasing $k$ when $k$ is large has little effect on prices. But. when $k$ is low, prices move with $\mathrm{k}$.

\section{Conclusions}

We report on some double-auction. two-market experiments where subjects had to satisfy an inequality involving the use of credit. The experiments persuasively display two regimes, characterized by high and low credit availability (parameter $\mathrm{k}$ ). The critical value of credit at the common boundary of the two regimes has a compelling interpretation as the maximal credit use (among consumers) at the Arrow-Debreu equilibrium of the abstract economy naturally associated to our experimental environment.

Our rnain results are that changes in the availability of credit:

(a) have minor and unsystematic effects on real and nominal variables in the high-credit regime:

(b) have substantial effects, both real and nominal. in the low-credit regime.

Fact (a) can be interpreted as follows. If credit availability is high, then the credit constraints are nonbinding, and can be ignored. The experiment then follows the tradition of relatively efficient double auctions inaugurated by Smith (1962) and continued by many others, including the later, two-market experiments of Goodfellow-Plott (1990) and Lian-Plott (1994). Given efficiency. it is not surprising that the outcomes resemble the equilibria of a price-taking model.

Fact (b) is experimentally robust. It is consistent, we argue, with a price-taking model with credit constraints. But the correspondence between experiment and abstract model is less clear-cut than in the high credit regime.

Fact (b) suggests to us that the availability of credit facilitates, in subtle ways incompletely captured by price-taking assumptiions, the coordination of consumption and production needed for realizing the potential gains from trade in two connected markets. Once inefficiencies appear at low credit levels, the price-taking theoretical framework becomes less persuasive as a model of behavior in double-auction markets. 
Appendix

A1. Description of the experiment

The experiments are performed in both markets simultaneously, using the Multiple Unit Double-Auction software. (The reader can consult Plott (1991) for details of the operation). Units of output and input are exchanged for Leexeta, the lab currency. Profits, as well as the amount of credit plus the balance of receipts and outlays (which appear as a number on the upper right corner of each screen) are also computed in LeeXeta, which has a known rate of exchange with Peseta. This is the currency in which the experimental subjects retrieve their accumulated profits at the end of the experiment. All subjects receive a minimum payment of 500 Peseta (about US\$ 3.85) for participation in the experiment, while the average payment is around 2800 Peseta (US\$21.54). A typical experiment lasts from two to two and a half hours.

An experiment starts with the reading of the instructions. answering a test to verify the subject's understanding of them, and an automated practice period to enable subjects to become used to the computer's commands. After this, we run two practice periods of 10 minutes each. When these preliminaries are over, the experiment begins. It lasts for several periods, never less than five, with a duration of 7 minutes the first two periods, and 6 minutes the remaining periods 10 .

\section{A.2. Instructions (in Spanish)}

I. Esencia del experimento

Este es un experimento en el que tirnes que tomar decisiones de compra y venta. Las instrucciones son simples y, sil las sigues y aplicas con atención, puedes ganar unas pesetas. Tu premio es proporcional a los beneficios que obtengas en el rxperimento. Si tienes pérdidas no ganarás nada,. ni nos tendrás que pagar nada a nosotros.

1) En este experimento vamos a simular dos mercados, que llamamos A y B.

2) Si eres "Participante de tipo 1", tal como consta en las hojas que te adjuntamos, lee este apartado. Si no, pasa directamente al apartado denominado "Participante de tipo 2".

10 Some of the initial experiments lasted for 10 periods with a duration of 5 minutes each. It was observed that after four or five periods, the results stayed about the same, which made us decide in favor of shortening the number of periods, to reduce both drudgery and cost. 
Si eres "Participante de tipo 1", vendes el bien A en el mercado A y compras el bien B en el mercado B, a lo largo de los varios periodos de que consta el experimento. En las hojas adjuntas figuran los costes del bien A y los valores de canje del bien B. Es importante que entiendas qué significan los costes y los valores de canje. De manera que presta atención a la siguiente descripción.

Para VENDER una unidad de A debes imaginarte que primero la adquieres, y para ello pagas su coste, de manera que cada unidad de A que vendas te costará el coste que indica la tabla correspondiente. Por lo tanto, si vendes por encima del precio de coste harás un beneficio que se añadirá a los restantes beneficios que vayas realizando, mientras que si vendes por debajo de este precio de coste tendras unas pérdidas que se te descontarán de los restantes beneficios que puedas obtener.

Dos cosas importantes respecto a este coste:

La primera es que, tal como ves en la tabla correspondiente, cada unidad tiene un coste distinto, de manera que cada unidad que adquieras para vender te puede costar más que la anterior, etc.

La segunda cosa importante es que solamente te cuestan las unidades que vendes. Por ejemplo, si no vendes nada de A, tus beneficios en este mercado serán cem, pero no negativos. Es decir, solamente tienen coste las unidacles de $A$ que vendas.

Al COMPRAR una unidad de B debes fijarte en su valor de canje, tal como consta en la correspondiente tabla. Este valor de canje es el valor que nosotros te damos por este bien B. Por lo tanto, si compras por debajo de este valor de canje obtendras un beneficio, tanto mayor cuanto mayor sea la diferencia entre el valor de canje y el precio que pagas. Por otro lado, no tendría sentido comprar por encima del precio de canje porque tendrías una perdida. Observa, finalmente, que el valor de canje varia con el numero de unidades adquiridas.

Tus beneficios, en proporcicin a los cuales ganarás tu premio en pesetas, se calculan al final de cada periodo de que consta el experimento, y no son más que la suma de los márgenes que obtengas entre los precios de venta de las unidades de A que vendas y los costes de estas unidades de A, más los márgenes que obtengas entre los precios de compra de B y los valor de canje de las unidades de B adquiridas.

3) Si eres "Participante de tipo 2", compras el bien A en el mercado A, lo transformas en B y, luego, vendes el bien B en el mercado B, a lo largo de los varios periodos de que consta el experimento. En las hojas adjuntas figura una tabla de transformacibndel bien A en el bien B.

Observa que a medida que vas adquiriendo mas unidades de A, la cantidad de B que puedes obtener a partir de una unidad de $\mathrm{A}$ va disminuyendo.

Tus beneficios, en proporción a los cuales ganarás tu premio en pesetas, se calculan al final de cada periodo de que consta el experimento, y no son más que la suma de los precios que obtengas por la venta de las unidades de B que vendas, menos los precios de las unidades de A que compres.

4) Tanto si eres "Participante de tipo 1" como "Participante de tipo 2", para comprar debes disponer de efectivo (CASH ON HAND). La cantidad de efectivo de que dispones aparece en la esquina superior derecha de tu pantalla. Observa que al principio del experimento aparecera alli una cantidad de efectivo, que puede ser cero o cualquier numero entero positivo. A medida que vendas, esta cantidad se ira incrementando con los ingresos procedentes de la venta, y a medida que compres esta cantidad ira disminuyendo por el importe de la cornpra. Si llega un momento en que la cantidad de efectivo de que dispongas sea inferior al precio al que se está pagando el bien que deseas comprar, o deberás dejar de comprar o deberás vender algo para aumentar tu efectivo con el que pagar la compra deseada.

5) Tanto si eres "Participante de tipo 1" como "Participante de tipo 2", la información que contienen las hojas de cálculo puede ser distinta para cada persona y es, por ello, estrictamente CONFIDENCIAL. ES FUNDAMENTAL QUE ESTA INFORMACION NO SE TRASMITA A MNGUNA OTRA PERSONA. Si SE constata que esta información es compartida se dará inmediatamente por concluido el experimento.

\section{Mecánica del experimento}

Desgraciadamante el programa con el que se realiza el experimento está en ingles. Esto no deberia constituir un problema grave puesto que el numero de palabras que aparecen en cada pantalla es pequeño. En los párrafos siguientes indicaremos la traducción castellana de las palabras en ingles que aparecen en la pantalla.

Durante todo el experimento cada individuo puede actuar bien como comprador (BUYER), o como vendedor (SELILER). En tu caso serás comprador en un mercado y vendedor en el otro. El mercado en el que compres y el mercado en el que vendas vienen determinados por el tipo de Participante que seas. En cada tranraccibn que lleves a cabo sólo puedes vender una unidad, esto es la cantidad (QNTY=Quantity) siempre será 1. Por ello, conviene que fijes tu atención en los precios (PRICE).Por supuesto, durante cada periodo puedes llevar a cabo más de una transacción y, por lo tanto, vender (comprar) mas de una unidad. Esto es, una vez que hayas vendido (comprado) tu primera unidad, puedes vender (comprar) una segundn y asi sucesivamente.

Dotaciones iniciales

Al inicio de cada periodo, a cada participantre se le dotara de una cantidad inicial de A, que quedará registrada como sus existencias (INVENTORY) iniciales. Esta dotacibn será la misma al comienzo de cada periodo de que consta el experimento. Cnda participante podrá disponer de sus dotaciones iniciales como o desee. Notese que estas existencias iniciales pueden ser iguales a 0.

Asimismo, al inicio de cada periodo los participantes recibiran una suma de dinero en efectivo de $\boldsymbol{X}$ leexetas que aparecerá en la esquinn superior derecha de su pantalla. Nbtese que la cantidad de dinero en efectivo(CASH: ON HAND) puede ser igual a 0.

\section{Funcionamiento del sisterna}

Participante de Tipo 1 
Durante cada periodo, cada participante del tipo 1 puede vender y comprar, de una en una, tantas unidades como desee de A y B respectivamente. Estas transacciones quedarän registrados en la casilla de existencias (INVENTORY). Al final del período cada unidad de B en existencias (INVENTORY) sera canjeada automaticamente de acuerdo con los valores de canje descritos en el cuadro de Valores de $\mathbf{w} \mathbf{j}$ e que se adjunta. La primera unidad será canjeada al valor de canje que se detalla en la primera fila del cuadro. La segunda unidad al valor unitnrio de la segunda fila y así sucesivamente.

Participante de Tipo 2

Durante cada periodo, cada Participante del tipo 2 puede comprar tantas unidades como desee de A (siempre que disponga del efectivo necesario) y transformarlas en unidades de B que podrá intentar vender. Esta transformación se realiza pulsando dos veces seguidas la tecla F4 y luego la tecla ESC para volver al mercado. Notarás que, como consecuencia de la transformación, tus existencias (INVENTORY) de $\mathrm{B}$ aumentarán de acuerdo con la tabla de transformación que te adjuntamos.

Nótese que, para los participantes de tipo 2, sus existencias (INVENTORY), tanto de A como de B carecen de cualquier valor.

\section{A3. Tables (in Spanish)}

The tables are handed to the subjects to facilitate their computations.

Participante de tipo 1

Penodo \#

de identificación

(ID)

Ventas de A

\begin{tabular}{|c|c|c|c|}
\hline $\begin{array}{c}\text { Unidad } \\
(1)\end{array}$ & $\begin{array}{c}\text { Precio } \\
\text { de venta de A } \\
(2)\end{array}$ & $\begin{array}{c}\text { Coste } \\
\text { deA } \\
(3)\end{array}$ & $\begin{array}{c}\text { Beneficios } \\
(2)-(3)\end{array}$ \\
\hline 1 & & 10 & \\
\hline 2 & & 150 & \\
\hline 3 & & 400 & \\
\hline 4 & & 10010 & \\
\hline 5 & & 1000 & \\
\hline 6 & & 1000 & \\
\hline 7 & & 1000 & \\
\hline 8 & & 1000 & \\
\hline 9 & & 1000 & \\
\hline 10 & & & \\
\hline
\end{tabular}

Compras de B

\begin{tabular}{|c|c|c|c|}
\hline $\begin{array}{c}\text { Unidad } \\
(1)\end{array}$ & $\begin{array}{c}\text { Valor decanje } \\
\text { según unidad } \\
(2)\end{array}$ & $\begin{array}{c}\text { Precio } \\
\text { de compra de B } \\
(3)\end{array}$ & $\begin{array}{c}\text { Beneficios } \\
(2)-(3)\end{array}$ \\
\hline 1 & 98 & & \\
\hline 2 & 88 & & \\
\hline 3 & 78 & & \\
\hline 4 & 70 & & \\
\hline 5 & 60 & & \\
\hline 6 & 50 & & \\
\hline 7 & 43 & & \\
\hline 8 & 33 & & \\
\hline 9 & 25 & & \\
\hline 10 & 15 & & \\
\hline 11 & 10 & & \\
\hline 12 & 5 & & \\
\hline 13 & 0 & & \\
\hline 14 & 0 & & \\
\hline
\end{tabular}


Participante de tipo 1

Penodo \#

Número

de identificación

(ID):

Ventas de A

\begin{tabular}{|c|c|c|c|}
\hline $\begin{array}{c}\text { Unidad } \\
(1)\end{array}$ & $\begin{array}{c}\text { Precio } \\
\text { de venta de A } \\
(2)\end{array}$ & $\begin{array}{c}\text { Coste } \\
\text { de A } \\
(3)\end{array}$ & $\begin{array}{c}\text { Beneficios } \\
(2)-(3)\end{array}$ \\
\hline 1 & & 35 & \\
\hline 2 & & 310 & \\
\hline 3 & & 400 & \\
\hline 4 & & 1000 & \\
\hline 6 & & 1000 & \\
\hline 7 & & 1000 & \\
\hline 8 & & 1000 & \\
\hline 9 & & 1000 & \\
\hline 10 & & 1000 & \\
\hline
\end{tabular}

Compras de B

\begin{tabular}{|c|c|c|c|}
\hline $\begin{array}{c}\text { Unidad } \\
(1)\end{array}$ & $\begin{array}{c}\text { Valor decanje } \\
\text { según unidad } \\
(2)\end{array}$ & $\begin{array}{c}\text { Precio } \\
\text { de compra de B } \\
(3)\end{array}$ & $\begin{array}{c}\text { Beneficios } \\
(2)(3)\end{array}$ \\
\hline 1 & 98 & & \\
\hline 2 & 88 & & \\
\hline 3 & 78 & & \\
\hline 4 & 70 & & \\
\hline 5 & 60 & & \\
\hline 6 & 50 & & \\
\hline 7 & 43 & & \\
\hline 8 & 33 & & \\
\hline 9 & 25 & & \\
\hline 10 & 15 & & \\
\hline 11 & 10 & & \\
\hline 12 & 5 & & \\
\hline 13 & 0 & & \\
\hline 14 & 0 & & \\
\hline
\end{tabular}

\section{A4. Test (in Spanish)}

The test was intended to verify the subjects' understanding of the instructions.

PARTICIPANTES TTPO 1

Las siguientes preguntas nos permitiran saber si has cornprendido correctamente las instrucciones de este experimento. Calcula tus resultados antes de buscar la respuesta correcta, pues si te has equivocado al interpretar los datos que te damos, podrias encontrar más de una respuesta que parezca adecuada.

Toma la siguiente tabla como datos para tus respuestas:

\begin{tabular}{|c|c|c|c|}
\hline $\begin{array}{c}\text { Unidad } \\
(1)\end{array}$ & Precio de Venta de A & Coste de A & $(3)$ \\
\hline 1 & & 10 & $\begin{array}{c}\text { Beneficios } \\
(2)-(3)\end{array}$ \\
\hline 2 & & 20 & \\
\hline 3 & & 60 & \\
\hline
\end{tabular}


I...Supón que al final de un periodo has vendido 3 unidades de bien A en el mercado A. ¿Cuáles han sido tus costes totales?

a) 60

b) 90

c) 20

II. Si al final del periodo has vendido dos unidades de bien A, la primera a $\mathbf{5 0}$ y la segunda a 40, ¿cuáles son los beneficios que has obtenido?
a) 60
b) 70
c) 0

III. Supón que al final del periodo has vendido tres unidades del bien A a los precios de 50, 40 y 20, pero en esta ocasión tus costes son de 40 por la primera unidad, 40 por la segunda y 60 por la tercera unidad de A. ¿Cuáles son tus beneficios?
a) -30
b) 0
c) 30

\section{PARTICIPANTES TIPO 2}

Las siguientes preguntas nos permitiran saber si has comprendido correctamente las instrucciones de este experimento. Calcula tus resultados antes de buscar la respuesta correcta, pues si te has equivocado al interpretar los datos que te damos, podrías encontrar mas de una respuesta que parezw adecuada.

Supón que tienes la siguiente tabla de transformacion:

\begin{tabular}{|c|c|}
\hline Unidades de A & Onidades de B \\
\hline 1 & 3 \\
\hline 2 & 3 \\
\hline 3 & 1 \\
\hline
\end{tabular}

I. Si en un periodo has adquirido 3 unidades del bien $\mathrm{A}$, ¿de cuántas unidades de $\mathrm{B}$ dispones para vender en el mercado B?
a) 7
b) 1
c) 9

Para las siguientes dos preguntas, imagina que has adquirido tres unidades de bien A a los precios $40,25 \mathrm{y}$ 145.

II. Al terrninar el periodo habiendo comprado las tres unidades de A y transformado en unidades de

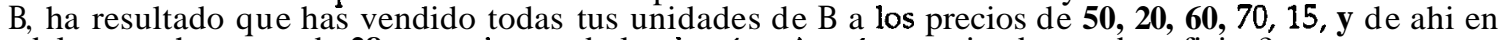
adelante, te han pagado $\mathbf{2 8}$ por cada una de las demás. ¿A cuánto ascienden tus beneficios?

a) 61

b) -160

c) 117

III. ¿Cuáles habrían sido tus beneficios si hubieras comprado las tres unidades de A a los precios indicados y solo hubieras podido vender tres unidades de B?

a) $\mathbf{- 1 6 0}$

b) -80

c) $\mathbf{- 3 0}$

\section{A5. Some price dynamics}

Next, we show the graphs of some price time series. The graphs have been chosen to further illustrate the stylized facts described in the paper, as well as to depict the dynamics of prices. Figure AS-1 shows the price dynamics when no credit is available to consumer-workers $(x=0)$. In this ten-period experiment, prices become lower and lower, as well as less and less volatile as the experiment develops. It may suggest that subjects become aware that some sort of steady state with low prices is reached and that there is not much 
margin for strategic pricing. This complacency may be unwittingly driven by a rather high efficiency of the market, in spite of a very skewed distribution of payoffs (in the last period, 2287 LeeXetas for consumer-workers vs. 6 LeeXetas for consumer-producers) ${ }^{11}$.

11 All the (experiments show a very asymmetric distribution of payoffs . but this is an extreme case. In the two other experiments presented in this appendix, the distribution of payoffs for the last period was 2352 vs 32 in the $\mathrm{k}=87$ experiment, and 2246 vs 181 in the $\mathrm{k}=300$ experiment. Notice that the fact that consumer-workers have no access to credit, if anything, it increases their payofi share. 

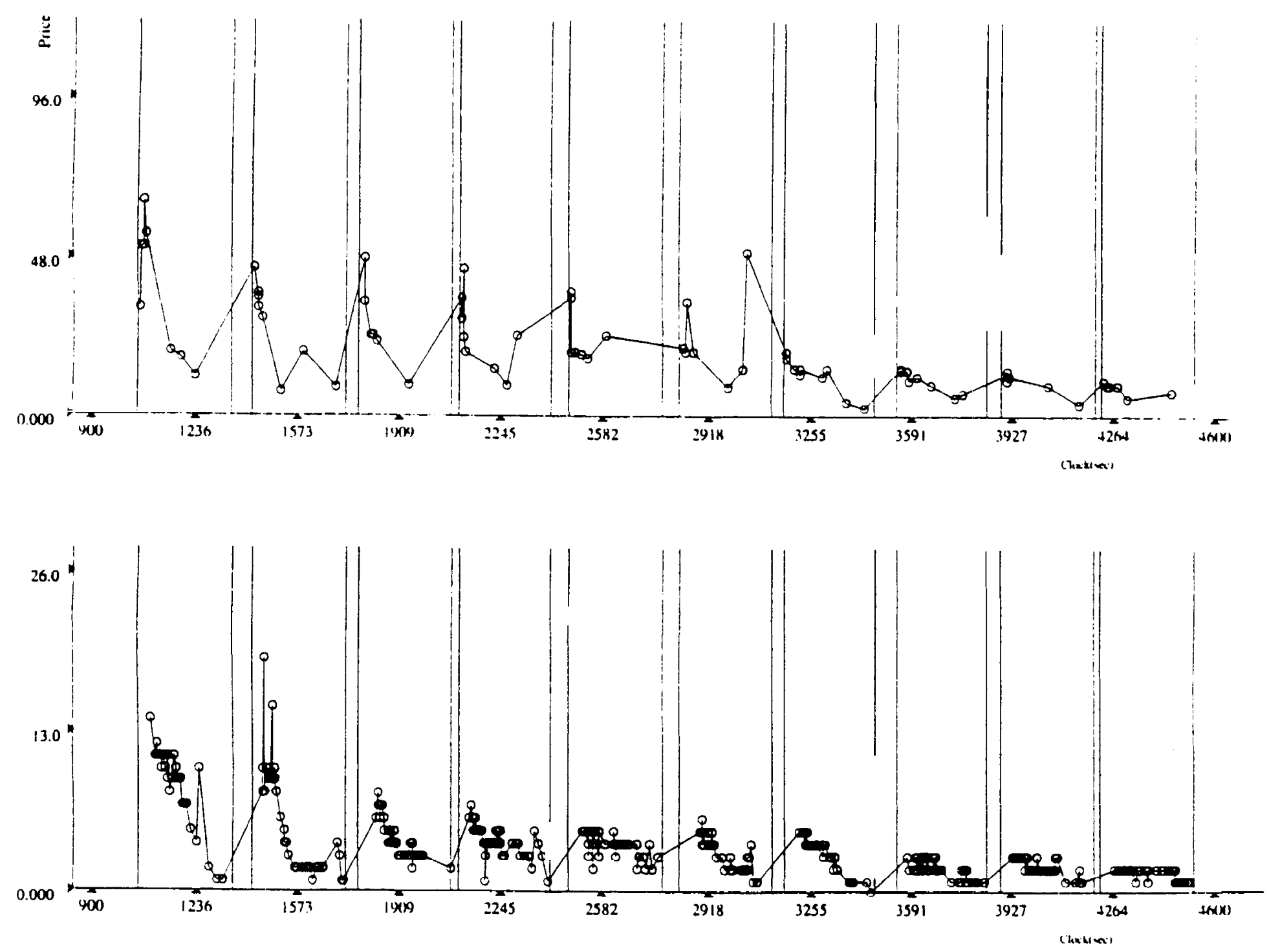

Fig AS-1. Price dynamics when consumer-workers have no access to credit $(k$ : 0). input prices are shown the upper graph, while output prices appear in the lower graph. 
Figure AS-2 shows the price dynamics in an experiment with nine periods and $\mathrm{k}$ $=87$, i. e., for a "critical" amount of credit (see Section 4.3). It is worth noting that now the experimental price range includes the Arrow-Debreu prices in both input and output markets. In contrast to the previous example. prices show a higher volatility. even in the last periods. This volatility is not inherent of situations with high credit constraints. In Figure AS-3 we present the price dynamics of a four-period experiment with $k=300$. These four periods followed immediately ( $w$ ith a two-minute delay) after a five-period experiment with $k=$ 750 , involving the same subjects. With $\mathrm{k}$ so large, the credit constraint is no longer binding, and subjects accommodate very quickly to a stable situation with hardly any change in prices. Notice also that prices stay very close to the Arrow-Debreu prediction. 

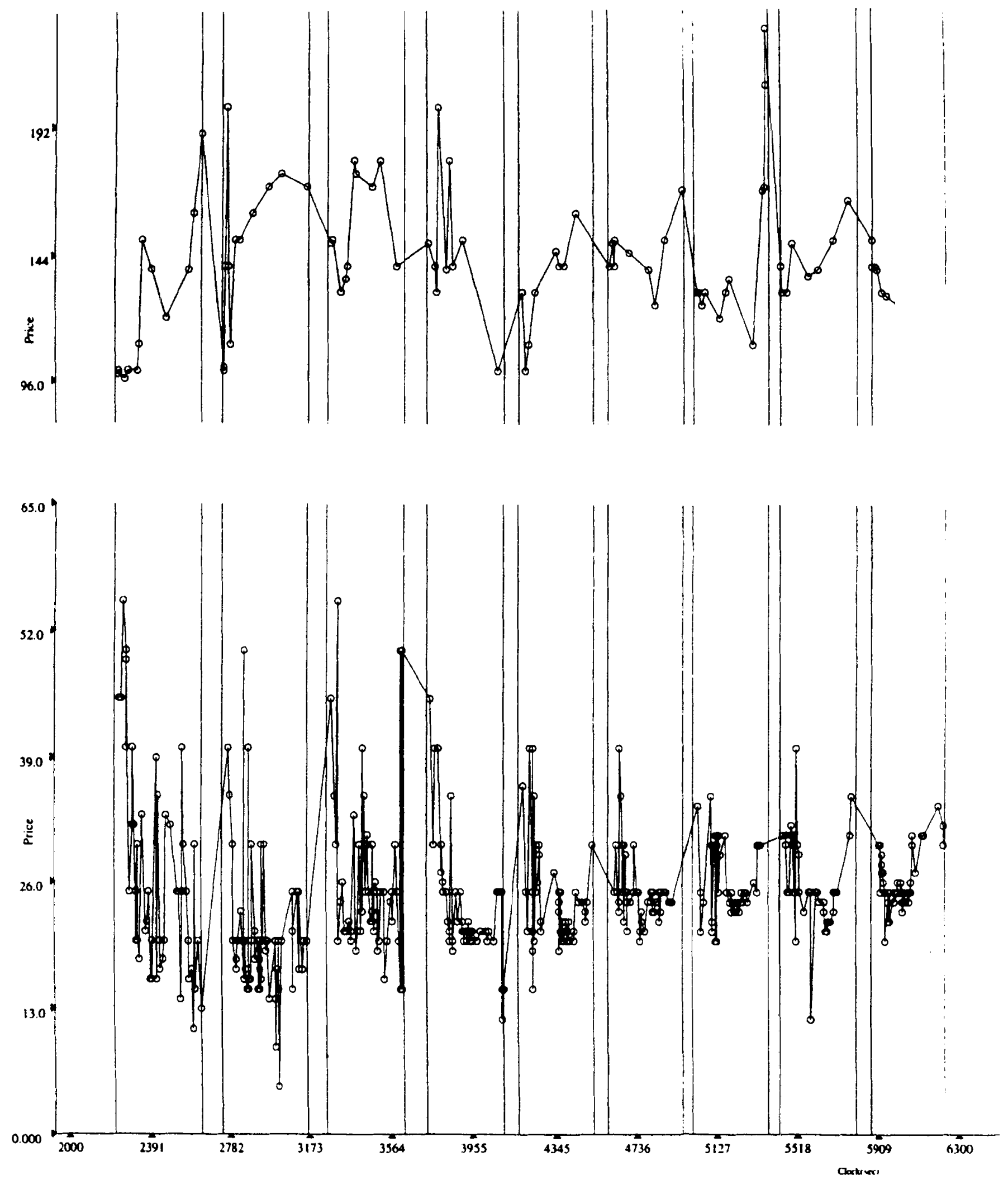

Fig A5-2. Price dynamics when consumer-workers have access to credit , with a credit limit of $k=87$. Input prices are shown the upper graph. while output prices appear in the lower graph. 

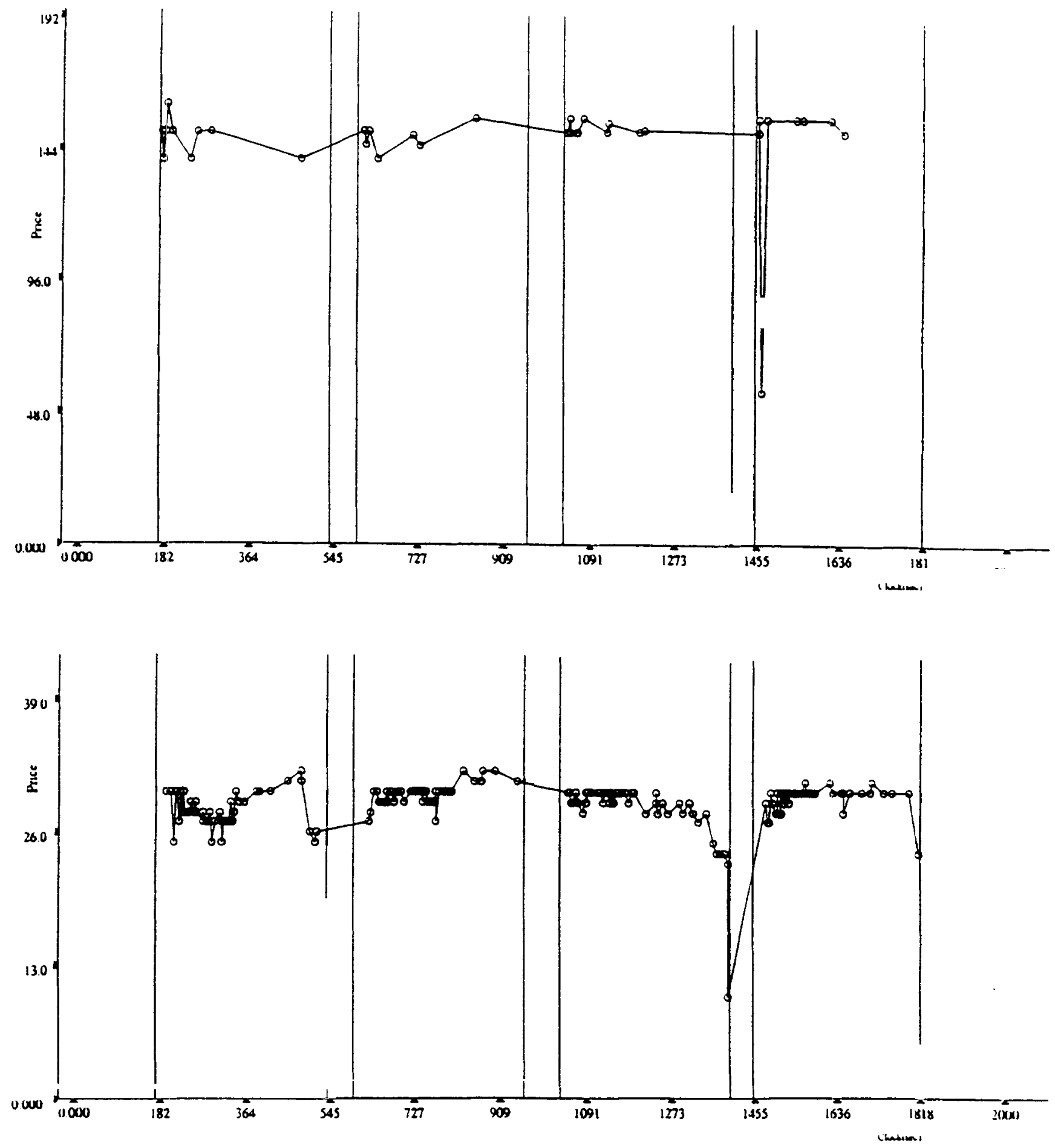

Fig A5-3. Price dynamics when consumer-workers have access to credit with a credit limit of $k=300$. Input prices are shown the upper graph, while output prices appear in the lower graph. 


\section{References}

Bosch, Antoni, and Shyam Sunder (1994), 'Tracking the Invisible Hand: Convergence of Double Auctions to Competitive Equilibrium', mimeo.

Friedman. Daniel (1993) 'The Double Auction Market Institution', in Daniel Friedman and John Rust, Eds. The Double Auction Market = Institutions, Theory and Evidence, Santa Fe Institute Studies in the Sciences of Complexity. Proceedings Volume XIV, Reading, MA: Addison-Wesley.

Goodfellow, Jessica, and Charles R. Plott (1990). "An Experimental Examination of the Simultaneous Determination of Input Prices and Output Prices," Southern Economic Journal vol. 56, issue 4, 969-983.

Lian. Peng, and Charles R. Plott (1944), 'General Equilibriurn, Markets, Macroeconomics and Money in a Laboratory Experimental Environment,' mimeo.

Plott. Charles R. (1991). 'A Computerized Laboratory Market :System and Research Support Systems for the Multiple Unit Double Auction.' Social Science Working Paper 783, Caltech.

Smith, Vernon L. (1962) 'An Experimental Study of Competitive Market Behavior', Journal of Political Economy . 70, 111-37.

Wilson, Robert (1987), "On Equilibria of Bid-Ask Markets', in George Feiwel, Ed.,Arrow and the Ascent of Modern Economic Theory, 375-414. New York: MacMillan. 